\title{
Insight
}

\section{Governance of Aquatic Agricultural Systems: Analyzing Representation, Power, and Accountability}

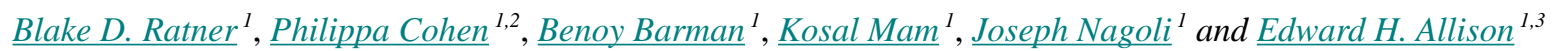

\begin{abstract}
Aquatic agricultural systems in developing countries face increasing competition from multiple stakeholders over rights to access and use natural resources, land, water, wetlands, and fisheries, essential to rural livelihoods. A key implication is the need to strengthen governance to enable equitable decision making amidst competition that spans sectors and scales, building capacities for resilience, and for transformations in institutions that perpetuate poverty. In this paper we provide a simple framework to analyze the governance context for aquatic agricultural system development focused on three dimensions: stakeholder representation, distribution of power, and mechanisms of accountability. Case studies from Cambodia, Bangladesh, Malawi/Mozambique, and Solomon Islands illustrate the application of these concepts to fisheries and aquaculture livelihoods in the broader context of intersectoral and cross-scale governance interactions. Comparing these cases, we demonstrate how assessing governance dimensions yields practical insights into opportunities for transforming the institutions that constrain resilience in local livelihoods.
\end{abstract}

Key Words: accountability; Bangladesh; Cambodia; civil society; coastal zone management; environmental governance; livelihoods; Malawi; Mozambique; power; social-ecological resilience; Solomon Islands; stakeholder representation; wetlands

\section{INTRODUCTION}

Aquatic agricultural systems in developing countries face increasing competition from multiple stakeholders over rights to access and use natural resources essential to rural livelihoods. Competition for land, water, wetlands, and fisheries resources spans sectors, from primary production sectors to infrastructure development, and scales, from local to international. There is therefore a pressing need to strengthen governance to enable equitable decision making amidst competition, building capacities both for resilience in ecosystems and livelihoods, and for transformations in institutions that perpetuate chronic poverty. In assessing the factors that influence these aspects of resilience and transformation in large social-ecological systems, governance characteristics are not sufficient in themselves to explain divergent outcomes. However, they play an influential role, interacting with characteristics of the user groups and the resource system (Ostrom 2009). Attributes of good governance such as inclusive decision making, polycentric and multilayered institutional arrangements, and strong mechanisms of accountability helping ensure just distribution of benefits, can be considered a foundation for diverse user groups and other stakeholders to build capacities to manage resilience (Lebel et al. 2006). Learning how to make improvements in governance is especially important as the demands of managing resource competition across sectors and across geographic scales intensify (Dietz et al. 2003, Adger et al. 2005, Wilson 2006).

Within the resilience literature, much of the reference to governance has focused on the normative aspects, by signaling the characteristics of "good governance" deemed consistent with the maintenance of social-ecological resilience. Relatively little attention, by contrast, has been given to the mechanisms of governance, in other words the building blocks that allow analysts to critically assess the positive and negative attributes of a given governance context. There have also been few practical applications, demonstrating how tools for governance analysis can help build an understanding among local actors of the possible pathways to change. We aim in this paper to present an analytical research approach that will address both these shortcomings. To achieve this we present a framework to analyze the governance context for development of aquatic agricultural systems, intended as a tool to observe and compare differences across multiple cases and as an aid to action research. For the purpose of iteratively developing and refining an analytical framework such as this, the case study approach is particularly well suited (Flyvbjerg 2006).

We focus on developing country environments where aquatic resources play a critical role in rural livelihoods, poverty reduction, and food and nutritional security. Occurring "along freshwater floodplains, coastal deltas, and inshore marine waters," these aquatic agricultural systems (AAS) "are characterized by their dependence on seasonal changes in productivity, driven by seasonal variation in rainfall, river flow, and/or coastal and marine processes" (WorldFish Center 2011:2). By broadening the focus from individual production sectors, i.e., fisheries, crop agriculture, livestock, aquaculture, to integrated environmental, food production and livelihood systems, the AAS perspective aims to bring greater coherence to attempts to govern these systems for their contribution to food security and poverty reduction. The emphasis on 
resilience of livelihoods to multiple stresses and shocks demands a systems perspective in development planning and implementation. It recognizes that building social, political, and economic rights is an integral element of poverty reduction, and a necessary foundation for efforts to build resilience and adaptive capacity (Allison et al. 2011). Also, it recognizes that in cases where current production systems are failing to meet the needs of local resource users, more fundamental transformations are needed (Walker et al. 2010).

We summarize a framework for analyzing the governance context for AAS development, focused on three dimensions: stakeholder representation, distribution of power, and mechanisms of accountability. To demonstrate the utility of such a framework, we present four case studies, addressing protected riverine wetlands in northern Cambodia, seasonal floodplain systems in Bangladesh, transboundary management of Lake Chilwa in Malawi and Mozambique, and artisanal marine fisheries in Solomon Islands. In each case, the particular challenges of small-scale fisheries and aquaculture development are presented in the context of broader intersectoral and cross-scale governance interactions. These cases highlight the formal and informal mechanisms that hold decision makers accountable toward poor and marginalized groups, including the role of bridging organizations that improve communication across sectors and geographic scales, and the role of civil society advocacy. We discuss the lessons and challenges of strengthening cross-scale governance in AAS in comparative perspective, including its contributions to resilience and institutional transformation. In the concluding section, we reflect on the benefits and limitations of this analytical approach, and identify priorities for future research to understand and strengthen governance of AAS systems globally.

\section{ANALYZING THE GOVERNANCE CONTEXT}

Pursuing improvements in governance is not merely a technical process involving choice among design options, but a contested process of change, requiring deliberation over societal goals and underlying values (Armitage 2008). It is important, therefore, that the analytical framework used to assess the governance context be critical rather than normative, in the sense that the description and assessment of how things are is distinct from the discussion of how things ought to be. It should also be suitable for use across a diversity of sociopolitical settings, simple enough to be understood by the resource users themselves, and therefore appropriate for use in action research settings where the goal is to gain practical insights that can be applied in successive cycles of learning, action, and reflection. The accumulated experience of integrating governance objectives into development assistance over the last two decades confirms that many of the most promising opportunities exist at local levels, requiring deliberation over locally determined "best-fit" options as opposed to "best practices" imported from other countries
(Carothers and de Gramont 2011). Learning from such local innovations can also provide a foundation for policy reforms and institution building at larger scales.

The governance context of AAS refers to the domain in which people's authority to use, manage, or otherwise influence natural resources is exercised. This includes the formal legal and institutional framework as well as the informal sets of norms, social networks, and power relationships that guide and constrain stakeholder interactions with one another and with the natural environment. To capture this context, approaches such as adaptive governance (Olsson et al. 2006) and interactive governance (Kooiman et al. 2008) take a broad perspective, comprising multiple stakeholders, not only government, and their interactions across system scales. Our framework builds on those foundations. For our purposes, however, the shortcoming of these approaches is that they are primarily oriented toward theory-building and expert analysis in reference to fairly abstract ideals such as "polycentric institutions that are nested, quasi-autonomous units operating at multiples scales" (Olsson et al. 2006) or a composite evaluation of "governability" for particular resource systems (Kooiman et al. 2008). This makes them difficult to adapt for collaborative assessments and action planning with local stakeholders. As Leach et al. (2010) point out, a reliance on expert analysis oriented by preconceived ideals of good governance entails a "danger of simply upholding dominant 'expert' views and supporting those in power, marginalizing the perspectives and priorities of the poor" (Leach et al. 2010:90-91).

By contrast, the framework we outline here is more practiceoriented and intended to be simple and adaptable enough to be used jointly with local stakeholders for analyzing the governance context of a given social-ecological system (SES) and the pathways to influencing change within this. As such it also aims to avoid the "essentialist" message of the good governance agenda, adopting a practical orientation concerned less with abstract ideals of system design, working instead to identify pathways to influence change toward "good enough governance" (Grindle 2011). "Given the limited resources of money, time, knowledge, and human and organizational capacities," writes Grindle (2011:S199), "practitioners are correct in searching for the best ways to move towards better governance in a particular country context." Moreover, because we focus on guiding questions for analysis rather than predefined goals, a collaborative application of the framework can enable dialogue over locally relevant priorities for resilience and adaptation.

In identifying the dimensions for governance analysis, we draw on the critical strain of research that has grappled empirically with the outcomes of governance reform efforts in areas including forests, water, and climate change adaptation (e.g., Agrawal and Ribot 1999, Ribot 2002, Lemos 
and Agrawal 2006). This research is oriented by several key observations. First, who is involved in or influences decision making has significant bearing on the content of decisions and their equity. Second, power is multifaceted, requiring attention to shifts in different aspects of decision-making authority among actors. Third, the outcomes of such shifting relationships of power depend critically on mechanisms of accountability, both formal and informal.

Our analytical framework therefore focuses on these three distinct dimensions:

- Stakeholder representation: Which actors are represented in decision making and how?

- Distribution of authority: How is formal and informal authority distributed with regard to decisions over resource access, management, enforcement, dispute resolution, and benefit sharing?

- Mechanisms of accountability: How are power-holders held accountable for their decisions, and to whom?

These three dimensions of representation, authority, and accountability combine to characterize the governance context; understanding one without the others gives an incomplete picture and therefore yields little insight into pathways for change. For example, decentralization reforms (a redistribution of authority) that increase local government responsibility for common-pool resource management, while neglecting to provide channels for community voice (stakeholder representation) and systems of redress in the case of abuse of power (mechanisms of accountability) may create incentives for elite capture rather than equitable or sustainable management (Agrawal and Ribot 1999). In Figure 1, we provide key questions to help orient analysis of each of these three dimensions of governance, and highlight issues of particular concern that often merit attention in developingcountry AAS specifically.

Analysis along these three dimensions also allows practitioners to conceptually separate an assessment of the governance context from an evaluation of outcomes, including resilience and adaptability (Ratner et al. 2013). Resilience is defined as the capacity "to absorb disturbance and reorganize while undergoing change so as to retain essentially the same function, structure, identity, and feedbacks" (Walker et al. 2004). For the purposes of this discussion, we are principally concerned with resilience in the ecosystem characteristics that contribute to sustainable livelihoods in AAS, as well as resilience of those livelihoods to shocks and stresses, whether economic, political, social, or environmental. These include chronic stresses such as resource extraction that degrades soil quality or fish abundance, for example, or competition among users across different sectors, such as infrastructure development, energy production, or tourism, as well as shocks such as cyclones, drought, disease epidemics, civil conflict, or spikes in the price of foods and fuel.

Adaptability is "the capacity of actors within a system to influence resilience" (Walker et al. 2004). Here we are concerned with adaptive capacity across multiple levels, from households to the institutions of market, state, and civil society at local, national, and international scales. Because developing-country AAS are generally characterized by intensifying competition, the ability to manage this competition equitably is a central feature of effective governance. However, we also recognize that improving livelihoods requires confronting institutions and structures that perpetuate social exclusion, vulnerability, and poverty. Examples include gender discrimination, along with exclusion from decision making of certain ethnic groups, classes, castes, or economic groups such as artisanal fishers or nomadic pastoralists. Although these power structures may have deep cultural and historical roots, they are also reflected in current governance processes and institutions. In this respect, intentional transformation of governance institutions may be a necessary step toward the longer term goal of resilient livelihoods.

While maintaining this distinction between context and outcomes, the framework nevertheless enables practitioners to address the questions that have animated research concerned with institutional design for resilience in SES. Lebel et al. (2006), for example, propose three pairs of "positive attributes" of governance deemed essential to building the capacities of stakeholder groups to manage resilience. Inclusive and deliberative decision making, with effective debate, room for dissent, and mechanisms for negotiation, are attributes of stakeholder representation. Polycentric and multilayered institutional arrangements characterize particular aspects of distribution of authority. Lines of downward, upward, and horizontal accountability describe the mechanisms of accountability as they function in practice, while just distribution of benefits and involuntary risks (social justice) can be considered an outcome of these mechanisms functioning well.

By focusing on the underlying dimensions or 'building blocks' of governance rather than a select set of positive attributes, the framework proposed here provides a simple toolkit readily applied in collaboration with local stakeholders to assess the governance context in relation to locally defined goals of resilience or institutional transformation. By first describing the governance context as it exists now, the framework is designed to help structure dialogue to identify obstacles and opportunities for transforming governance in positive directions. For each of the three dimensions, both formal and informal mechanisms typically function in parallel (see Figure 2 for illustrations). Analysis must focus on how decision making works in practice, which may diverge significantly 
Fig. 1. Key questions and considerations in analyzing the governance context for development of aquatic agricultural systems.

\begin{tabular}{|c|c|c|c|}
\hline & \multicolumn{3}{|c|}{$\begin{array}{c}\text { Dimensions of governance affecting development } \\
\text { of aquatic agricultural systems }\end{array}$} \\
\hline & $\begin{array}{l}\text { Stakeholder } \\
\text { representation }\end{array}$ & $\begin{array}{l}\text { Distribution of } \\
\text { authority }\end{array}$ & $\begin{array}{l}\text { Accountability } \\
\text { mechanisms }\end{array}$ \\
\hline Key Question & $\begin{array}{l}\text { Which actors are } \\
\text { represented in } \\
\text { decision making and } \\
\text { how? }\end{array}$ & $\begin{array}{l}\text { How is formal and informal } \\
\text { authority distributed in } \\
\text { decisions over resource } \\
\text { access, management, } \\
\text { enforcement, dispute } \\
\text { resolution, and } \\
\text { benefit-sharing? }\end{array}$ & $\begin{array}{l}\text { How are power-holders } \\
\text { held accountable for their } \\
\text { decisions and to whom? }\end{array}$ \\
\hline Guidance for assessment & $\begin{array}{l}\text { Includes decision making } \\
\text { regarding specific } \\
\text { land, water, or fisheries } \\
\text { resources and also the } \\
\text { broader context of policy } \\
\text { and implementation that } \\
\text { influence the livehoods of } \\
\text { resource users and other } \\
\text { local stakeholders. }\end{array}$ & $\begin{array}{l}\text { Includes authority } \\
\text { regarding decisions over } \\
\text { resource tenure rules, } \\
\text { taxation, and basin or } \\
\text { coastal-zone planning, } \\
\text { including transboundary } \\
\text { arrangements. } \\
\text { Consider generic } \\
\text { governance reform trends, } \\
\text { such as decentralization, } \\
\text { regional integration, or } \\
\text { market liberalization. }\end{array}$ & $\begin{array}{l}\text { Applies equally to the } \\
\text { exercise of public and } \\
\text { private authority. } \\
\text { Measured in three } \\
\text { directions: upward } \\
\text { (toward higher level } \\
\text { authorities); horizontal } \\
\text { (to stakeholders } \\
\text { in other sectors or } \\
\text { localities); downward (to } \\
\text { resource users and other } \\
\text { community members). }\end{array}$ \\
\hline Issues of concern & $\begin{array}{l}\text { Representation of politically, } \\
\text { economically, or socially } \\
\text { marginalized groups, } \\
\text { which may include landless } \\
\text { poor, women-headed } \\
\text { households, internally } \\
\text { displaced persons, ethnic } \\
\text { minorities, etc. } \\
\text { Gender disparities in } \\
\text { representation often } \\
\text { critical at multiple scales. }\end{array}$ & $\begin{array}{l}\text { Clarity in distribution of } \\
\text { authority (overlaps can be } \\
\text { a source of conflict). } \\
\text { Appropriateness of } \\
\text { distribution in equity and } \\
\text { efficiency terms. } \\
\text { Capacity of institutions } \\
\text { endowed with certain } \\
\text { powers to execute them } \\
\text { effectively. } \\
\text { Adaptability of rights to } \\
\text { changing conditions. }\end{array}$ & $\begin{array}{l}\text { Relative strength of upward, } \\
\text { horizontal, and downward } \\
\text { accountabilities. } \\
\text { Transaction costs involved } \\
\text { in keeping decision makers } \\
\text { accountable. } \\
\text { Integration of } \\
\text { decision making across } \\
\text { sectors or horizontal } \\
\text { inequalities among } \\
\text { regional, ethnic, or } \\
\text { user groups. }\end{array}$ \\
\hline
\end{tabular}


Fig. 2. Examples of formal and informal mechanisms for three dimensions characterizing the governance context for development of aquatic agricultural systems. Adapted from Ratner and Allison (2012).

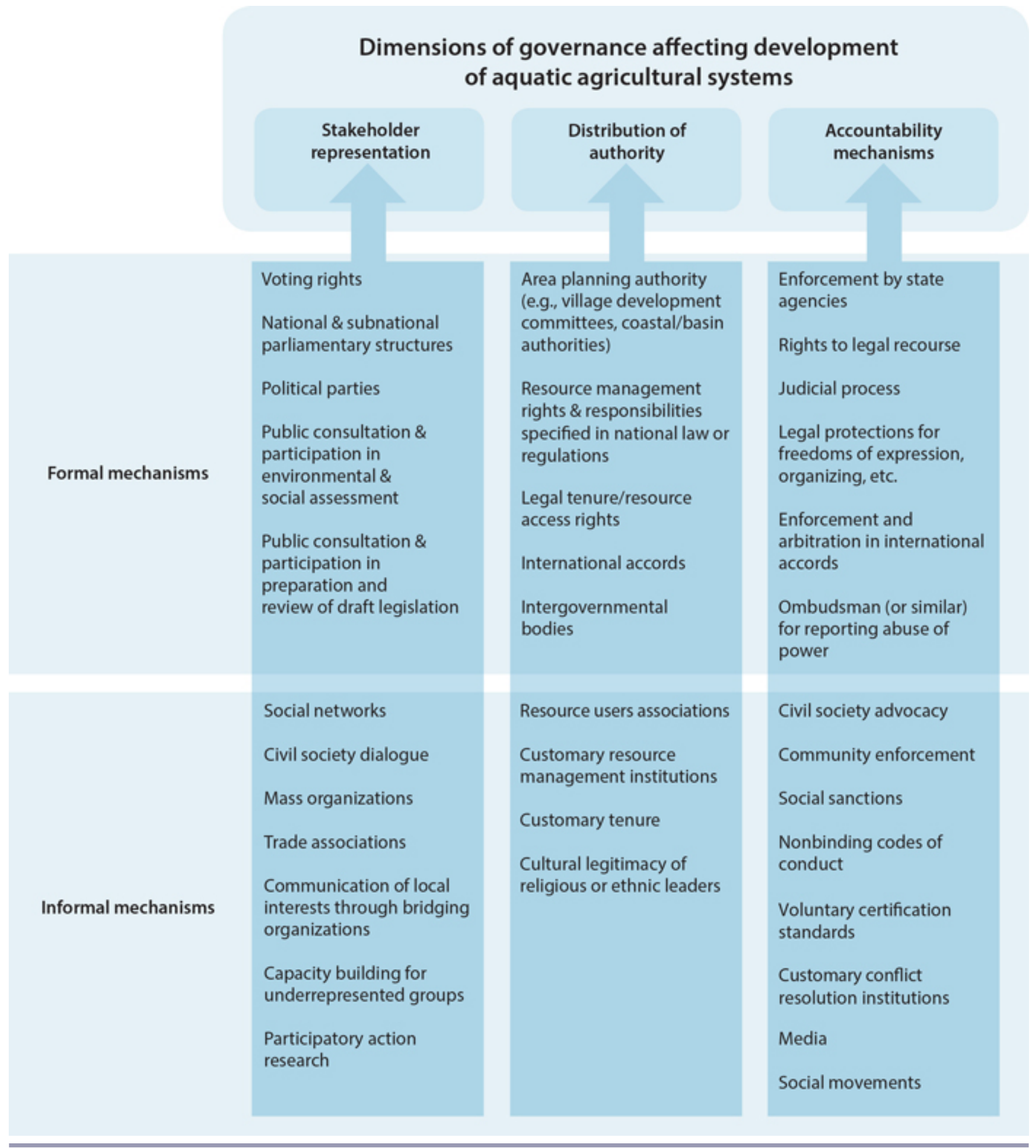


from how it is meant to work in principle (Carothers and de Gramont 2011). In describing mechanisms of representation, for example, partners should consider both formal mechanisms such as community representation in management committees, or local or regional bodies of government, along with informal mechanisms stakeholders use to represent their interests, such as social networks or advocacy organizations. Evaluating distribution of authority, likewise, calls for attention to both formally allocated authority, such as those granted to decentralized agencies of government, and powers assumed in practice. This would be the case, for example, when farmer cooperatives or local religious bodies regularly play a role in mediating decisions on resource access or environmental conflicts even if not their principal function.

Regarding mechanisms of accountability, formal channels such as the courts need to be considered alongside informal mechanisms such as civil society movements and the media. Rather than look at written laws and regulations alone, analysts need to examine the extent to which these are enforced, and whether they are applied equally or with bias against certain social groups. Even in places where informal, local enforcement mechanisms have historically functioned well without intervention of the state, increasing competition over valuable resources is placing growing importance on crossscale governance interactions (Thorburn 2000, Dietz et al. 2003, Berkes 2006). Governance institutions at higher levels may reinforce, undermine, or even destroy governance institutions specific to a focal SES (Ostrom 2009).

\section{CASE STUDIES}

We present four developing country case studies, employing the framework to analyze the governance context for AAS development in diverse ecological and socio-political settings. In an iterative process, we have used the framework to help organize the empirical work, with the cases providing a test to improve the coherence and utility of the framework, illustrating practical implications of efforts to analyze and improve stakeholder representation, distribution of authority, and mechanisms for accountability. Each case is focused on an initiative that seeks to improve the governance of aquatic agricultural systems and is part of an ongoing, long-term collaboration between WorldFish and partners in a multifaceted program of action research and capacity building (WorldFish Center 2011) to strengthen resilience of local livelihood systems. As typical of the action research approach (Whyte 1984), the goal of these initiatives is not only to understand the constraints to livelihood resilience but also to actively work with local partners to address these. The selection of cases is therefore purposive (Patton 1990), aiming to benefit from the depth of knowledge created by these relatively long-term engagements, the experience of one or more of the coauthors as a locally engaged researcherpractitioner, as well as to illustrate geographic and issue diversity. The case studies include descriptions of broad governance trends and characteristics as well as the more specific outcomes of collaborative efforts, in addition to insights concerning challenges that have not yet been addressed (see summary in Table 1). As these are all worksin-progress, the intention is not to describe ultimate outcomes but rather to illustrate the types of practical insights the framework can yield and the ways this can contribute to collaborative planning efforts.

\section{Strengthening community voices for conservation in the wetlands of Stung Treng, Cambodia}

The first case study is focused on actions at a very local scale. The Stung Treng Ramsar site is a protected wetland along some $40 \mathrm{~km}$ of the Mekong River mainstream in northeastern Cambodia. Recognized internationally for its unique biodiversity value, the area is also a source of livelihood for 20 villages, which depend on the floodplain and riverbanks to cultivate rice and other food crops. Subsistence fishing is the second major livelihood activity, and in the dry season attracts villagers from distant areas.

Since 2005, WorldFish and partners have facilitated a villagebased action research initiative working to build local commitment to protect Stung Treng resources, and engaging local government and the media to promote community livelihoods. The initiative, known locally as Salaphoum, addresses a deficit in local stakeholder representation in decision making and downward accountability of local government. Salaphoum supports four communities to collate and document local knowledge of environmental resources such as fish species, their habitats and migration patterns, and fishing gears and practices (Salaphoum 2009). Subsequently community-produced media are developed as tools for advocacy. To date, this initiative has influenced the designation of fish habitats for protection and formed a network among neighboring communities to protect fisheries resources. An outcome evaluation shows that villages in the area now share information much more effectively, troubleshoot shared problems such as deterring illegal fishers, and engage in collective action such as joint patrols between neighboring community fisheries (Halpern et al. 2010). The effort has also improved women's representation in decision making. In one instance, a community researcher credits her selection as chief in part to the skills she gained through the research collaboration (Salaphoum 2009).

Legal and administrative reforms have also increased the scope for community-based resource management in recent years, but overlapping authority and limited government capacity pose serious constraints. In this section of the river, the Fisheries Administration and NGOs have supported establishment of 21 community fishery organizations with authority to manage fisheries resources in public fishing grounds. Under the protected areas law (RGC 2008a), 
Table 1. Key observations from case studies. Outcomes of action research are shown in italics.

\begin{tabular}{|c|c|c|c|c|}
\hline Case & $\begin{array}{l}\text { Action research } \\
\text { initiative }\end{array}$ & Stakeholder representation & Distribution of authority & Accountability mechanisms \\
\hline Cambodia & $\begin{array}{l}\text { "Salaphoum" } \\
\text { initiative builds } \\
\text { local } \\
\text { commitment to } \\
\text { resource } \\
\text { protection and } \\
\text { capacities for } \\
\text { collaboration }\end{array}$ & $\begin{array}{l}\text { Historically low representation of } \\
\text { local stakeholders in provincial- and } \\
\text { national-level decision making. } \\
\text { Village-based research network helps } \\
\text { communities document } \\
\text { environmental change and resource } \\
\text { use, and subsequently influence } \\
\text { conservation management and } \\
\text { planning. }\end{array}$ & $\begin{array}{l}\text { Decentralization reforms have } \\
\text { increased the scope for community- } \\
\text { based resource management. } \\
\text { Research highlights misfit between } \\
\text { resource use rights and responsibility } \\
\text { for protection. }\end{array}$ & $\begin{array}{l}\text { Decentralization reforms introduce } \\
\text { democratically elected commune } \\
\text { councils, intended to represent local } \\
\text { development priorities and call on } \\
\text { services of line agencies. } \\
\text { Research collaboration improves } \\
\text { capacity of commune councils to } \\
\text { respond to local constituencies. }\end{array}$ \\
\hline Bangladesh & $\begin{array}{l}\text { Community- } \\
\text { based fish } \\
\text { culture } \\
\text { initiatives on } \\
\text { private and } \\
\text { publicly owned } \\
\text { floodplain lands } \\
\text { with multiple } \\
\text { beneficiaries }\end{array}$ & $\begin{array}{l}\text { Melandi Fishers Society (MFS) } \\
\text { members lacked representation in } \\
\text { production management, conflict } \\
\text { resolution, and benefit sharing. } \\
\text { Establishing accountability of local } \\
\text { authorities and support agencies } \\
\text { through action research made the } \\
\text { organization more representative, } \\
\text { including landless households, and } \\
\text { convinced better-off fishers to invest } \\
\text { in community-based efforts. }\end{array}$ & $\begin{array}{l}\text { Local communities organized under } \\
\text { the MFS gained legal access rights but } \\
\text { in practice the resource was captured } \\
\text { by local elites. } \\
\text { Improved advocacy roles by local } \\
\text { agencies/support providers } \\
\text { (supporting marginalized households } \\
\text { to assert their resource use rights) } \\
\text { stopped elite resource capture and } \\
\text { incursion by outsiders in illegal } \\
\text { fishing. }\end{array}$ & $\begin{array}{l}\text { Local government authorities and the } \\
\text { fisheries department had weak lines of } \\
\text { accountability to local communities. } \\
\text { Strengthened capacity of MFS } \\
\text { leadership and local authorities, } \\
\text { combined with renewed activism by } \\
\text { members, improved responsiveness } \\
\text { toward needs of poor households. }\end{array}$ \\
\hline $\begin{array}{l}\text { Malawi/ } \\
\text { Mozambique }\end{array}$ & $\begin{array}{l}\text { Lake Chilwa } \\
\text { Basin Climate } \\
\text { Change } \\
\text { Adaptation } \\
\text { Program } \\
\text { promotes } \\
\text { strengthened } \\
\text { stakeholder } \\
\text { engagement in } \\
\text { resource } \\
\text { planning across } \\
\text { the watershed }\end{array}$ & $\begin{array}{l}\text { Official data underestimated the } \\
\text { number of people involved in fishing, } \\
\text { processing, and trade. } \\
\text { Participatory monitoring of fish } \\
\text { catch and distribution of benefits has } \\
\text { motivated greater local participation } \\
\text { to influence management plans. }\end{array}$ & $\begin{array}{l}\text { Parallel systems aligned with local } \\
\text { chiefdoms and national government } \\
\text { sometimes conflict over authority to } \\
\text { set and enforce rules. } \\
\text { Research highlights challenges of } \\
\text { resolving competition and disputes } \\
\text { between management authorities, } \\
\text { negotiating competing resource uses } \\
\text { across sectors, and enabling } \\
\text { transboundary collaboration between } \\
\text { authorities of Malawi and } \\
\text { Mozambique. }\end{array}$ & $\begin{array}{l}\text { Lakeshore communities lack basic } \\
\text { services, reflecting a historically } \\
\text { limited responsiveness of government } \\
\text { and private sector to local priorities. } \\
\text { Participants in the fish value chain are } \\
\text { demanding more accountability from } \\
\text { government and private sector actors. }\end{array}$ \\
\hline $\begin{array}{l}\text { Solomon } \\
\text { Islands }\end{array}$ & $\begin{array}{l}\text { SILMMA } \\
\text { network aims to } \\
\text { increase } \\
\text { interagency } \\
\text { dialogue and } \\
\text { representation of } \\
\text { local } \\
\text { management, } \\
\text { NGO and } \\
\text { government } \\
\text { authorities }\end{array}$ & $\begin{array}{l}\text { Historically low representation of } \\
\text { local stakeholders in national-level } \\
\text { policy decision making. } \\
\text { SILMMA network facilitates local } \\
\text { representation at national and } \\
\text { international meetings discussing } \\
\text { local issues and national policies for } \\
\text { marine resource management. }\end{array}$ & $\begin{array}{l}\text { Historically low capacity to implement } \\
\text { marine resource management in rural } \\
\text { areas, exacerbated by difficulties } \\
\text { resolving state and traditional controls, } \\
\text { i.e., constitutionally protected } \\
\text { customary tenure. } \\
\text { SILMMA approach clarifies local } \\
\text { management authority and supports } \\
\text { state institutions to complement } \\
\text { customary management in areas such } \\
\text { as enforcement and dispute resolution. }\end{array}$ & $\begin{array}{l}\text { Community groups reliant on support } \\
\text { received via their partners, with only } \\
\text { one or two representatives from each } \\
\text { community in national level or other } \\
\text { meetings. } \\
\text { Research highlights that mechanisms } \\
\text { are required to ensure representation is } \\
\text { accountable to all sectors of the } \\
\text { community to ensure interests are } \\
\text { effectively and fairly represented. }\end{array}$ \\
\hline
\end{tabular}

management of the Ramsar site falls under the authority of the Ministry of Environment. The local fisheries and environment offices are poorly staffed and financed, and have difficulty monitoring the area partly because of high travel costs. Local officers have low wages and limited downward accountability, reporting not to local government but directly to the national ministries. As a result, some local officers reportedly levy informal fees from resource users, justified as supporting the cost of their operations.
One of the most significant obstacles to improving enforcement is distribution of authority, in particular, the misfit between resource use rights and responsibility for protection. According to the fisheries law (RGC 2006), outsiders enjoy the same use rights as local community members, provided they follow local management rules. However, when outsiders violate these rules, there are few avenues of recourse for community fishery leaders, who do not have the authority to apprehend offenders, only to report them. Outsiders are not subject to the same social sanctions 
that act as deterrents for community members, and in many cases they employ large-scale and sophisticated fishing gear, sometimes financed by powerful interests (Halpern et al. 2010).

Meanwhile, decentralization reforms outlined in the law on subnational administration (RGC 2008b) are introducing new opportunities to improve accountability. Local government units have typically been more responsive to local needs than fisheries and environment officers accountable to the central line ministries; however, they often lack the resources to provide much support. By allocating fiscal resources to local planning committees at commune, district, and provincial levels, the decentralization reforms should in principle help address this gap (Mam 2009). In most places, however, natural resource management has received low priority in commune planning processes in most places because of the immediate need for physical infrastructure and limited capacity in local government units. Salaphoum action research has helped to raise the profile of natural resource management concerns critical to local livelihoods with the commune councils, leading, for example, to actions that integrate protection of fisheries and flooded forests as priorities in Commune Investment Plans. At the same time, by involving national agencies, the initiative has helped strengthen their responsiveness to local priorities. In this example, assessing the governance context helped identify gaps in the implementation of decentralization reforms and corresponding opportunities to improve the representation of local voices in development planning and accountability of government authorities to local priorities for resource management.

\section{Expanding resource access through community-based fish culture in seasonal floodplains, Bangladesh}

The second case illustrates the interplay of stakeholder representation and accountability mechanisms in affecting livelihood outcomes under changing forms of resource tenure. Bangladesh has one of the largest inland fisheries in the world, with nearly 4.6 million ha of inland waters, yet intensive harvesting and land use change have reduced yields from natural floodplain fisheries. Augmenting natural productivity through fish culture is an important tool for strengthening the rural economy (Dey and Prein 2006). Although past fish culture interventions increased production, they have also resulted in fishers losing access rights (Haque et al. 2011), with negative effects on income of poor households (Toufique and Gregory 2008). For example, in some cases public floodplains leased to fisher groups are appropriated by influential people, with the benefits from fish culture accruing only to a few members.

Although there are various initiatives to introduce fish culture in privately owned floodplains through contracts between landowners and individual entrepreneurs, initiatives to bring public and privately owned floodplains under community- based systems with multiple beneficiaries are less common. In part this is because the approach is more demanding in its requirement for equitable institutions to balance the interests of fishers, landowners, and the landless (Haque et al. 2011). During 2005-2010, an initiative supported by the CGIAR Challenge Program on Water and Food experimented with such an approach, working both in publicly owned and privately owned floodplains (Joffre and Sheriff 2011).

The case of Beel Mail in Mohanpur at Rajshahi, a seasonal water body formed on publicly owned floodplains, illustrates the sharp divergence between distribution of authority in law and in practice. Local communities organized under the Melandi Fishers Society (MFS) gained legal access rights to the water body for a three-year period by participating in an auction, but in practice they were often excluded because the resource was captured by economically and politically influential local people. MFS members lacked representation in decisions regarding production management, conflict resolution, and benefit sharing. Elite capture of the Beel Mail floodplains stemmed from a serious lack of accountability in several respects: MFS was a weak institution with little internal commitment among its members; its leaders were influenced by local elites who captured the floodplains with token payments; and local government authorities and the Department of Fisheries, had weak lines of accountability to local communities.

The CGIAR initiative convened dialogue between the Department of Fisheries and other stakeholders, facilitated MFS meetings, helped restructure leadership selection processes and built organizational capacity, e.g., financial accounting and reporting. These forms of support led to a significant improvement in representation and accountability within the MFS, alongside improvements in downward accountability of local government authorities and support agencies. As more MFS members became actively involved in floodplain management, its leaders gradually became more accountable to members in assigning roles, assuring distribution of benefits, and maintaining active linkages with other local agencies to improve delivery of services. MFS increased its capacity and activity in advocating for community rights and communicating with local government, as well as negotiating and resolving conflicts. Elite capture was effectively stopped, with many withdrawing their claims on the resource, while those local elites who remained involved became active members of the MFS, providing financial and technical support to fish culture and management, and influencing government and private sector institutions to support community efforts. Illegal fishing by outsiders has ceased, and local landless households have benefited by harvesting small, nonstocked species. Harvests of both stocked and nonstocked fish have more than doubled, with a similar rise in income (Joffre and Sheriff 2011). 
This experience is notable for its success in addressing the problems of weak downward accountability and elite capture. Researchers engaged in the initiative built on many years of prior collaboration with the government to diagnose the stakeholder relationships and institutional dynamics, and learn from the outcomes of prior efforts. Key insights included the importance of supporting marginalized households to assert their rights to resource use and the value of engaging relatively better-off fishers in community-based efforts, which generated economic gains and encouraged others to participate (Haque et al. 2011). Where there was strong stakeholder representation from a diversity of user groups, including women and landless households, effective linkages with local government, and accountability mechanisms to ensure equitable distribution of benefits, similar results were achieved on privately owned floodplain lands. Where these governance features were lacking, outcomes were far less successful. At a floodplain at Pirgonj in Ranpur, for example, participation of members was far less consistent and leaders lacked an orientation toward consensus building, had less extensive networks with local institutions, and were less able to negotiate with local authorities and fisheries officers. As a result, the collective management institutions were both less accountable to their members and less effective at fostering accountability from local government and private landowners. Complaints over lack of transparency on the use of investment funds and disputes over distribution of benefits eventually stymied the initiative (Haque et al. 2011, Joffre and Sheriff 2011).

\section{Navigating intersectoral competition in the Lake Chilwa basin, Malawi and Mozambique}

The next case illustrates the challenge of managing resource competition amidst parallel authorities at multiple scales, and some of the strategies that can build accountability toward local resource users. Lake Chilwa lies in southeastern Malawi, spanning the border with Mozambique. A shallow, enclosed lake with a surrounding reed belt and a seasonally flooded plain, it is one of Africa's most productive lake fisheries (Njaya et al. 2011). The basin provides fertile land for over 1.6 million people in Malawi growing mostly rice in the wetlands and maize in upland areas. The relatively high population density (NSO 2008) is driving the expansion of cropland to marshes, forests, and other marginal areas. The lake's fish production is directly influenced by deforestation, upland agriculture, and soil erosion within the catchment that deposits phosphorous and other pollutants, as well as urban waste runoff from Zomba City (Government of Malawi 2000). The lake and its marshes also form an internationally significant wetland ecosystem, designated a protected Ramsar site.

An important feature of local governance is parallel systems of authority aligned with local chiefdoms and national government. Traditional management strategies involve a fishing calendar based on taboos and myths respected by the Lomwe, Yao, and Nyanja ethnic groups. These traditional management systems, although modified, are still being practiced in small, cohesive communities as found in the islands of Lake Chilwa (Chisi and Njalo) as well as Lake Malawi (Mbenji). In parallel, the Malawian government instituted a centralized system, with Department of Fisheries as the sole fishery management authority. However, in 1995, after the lake dried out and the fishery was temporarily depleted following a periodic drought, government authorities initiated a comanagement approach. Although some of the regulations formulated under centralized management were retained, others were changed to reflect management and monitoring roles assigned to the newly introduced Beach Village Committees. In some cases, these committees and traditional local leaders have come into conflict over authority to set and enforce rules (Kayambazinthu 1999, Njaya 2009).

Recently, the Lake Chilwa Basin Climate Change Adaptation Program introduced participatory monitoring, which serves to increase accountability of government and private sector actors. Fishers use logbooks to record catch, sales, and incomes, providing more detailed information than available from government statistics. A preliminary assessment of these records revealed that fishing effort on Lake Chilwa was previously underestimated by a factor of three to four, and suggested the number of people directly involved in the fisheries value chain is also far greater than indicated by official data. With this information in hand, fishers have become more proactive in calling on government to improve enforcement and to adjust management approaches in response to the shifting resource status. With new information tracking cash income from fish sales, fishers also became motivated to lobby for new services, including mobile banking at the fish landing beaches.

If such efforts succeed in strengthening fisheries comanagement systems in Malawi, and if the competition with traditional authorities is resolved, significant challenges will still remain at the lake basin scale. One dimension involves the interface between land, water, agriculture, and fisheries management. Agriculture authorities, for example, have promoted manual treadle pumps for irrigation to expand cropping on the lakeshore and riverbanks, inadvertently competing with efforts to protect critical aquatic habitats. So far, few institutions have developed to manage trade-offs and competition across sectors, such that poor users in particular are left to seek strategies to cope and adapt as livelihood opportunities shift. At the international scale, conflicts among fishers and between fisheries authorities in the two countries are frequent (Njaya 2007). Fishing restrictions in Mozambique are less developed than in Malawi, so seine fishers, for example, migrate to the Mozambican side of the lake during the closed season when they are not allowed to fish in Malawian waters. However, there is no joint committee or other institutional arrangement to handle such disputes or to undertake joint planning and management efforts, a significant 
gap in distribution of authority, and a challenge for future initiatives in the lake basin.

\section{Promoting networking and advocacy among coastal communities in the Solomon Islands}

The last case addresses challenges of improving coordination and representation at a broad geographic scale, in a setting with highly dispersed coastal communities. The population of Solomon Islands resides predominantly in rural and coastal areas, and is highly dependent on subsistence and small-scale agriculture and fisheries for food security and livelihoods (Bell et al. 2009). Situated within the coral triangle region of exceptionally high marine biodiversity, the country attracts global interest in the management and conservation of its marine resources (Coral Triangle Initiative 2009). Most land and nearshore marine areas are traditionally owned, and constitutionally protected customary systems allow clans with tenure to control resource access and use (Lane 2006). National environmental and fisheries legislation also regulate nearshore marine resource use; however, lack of capacity and difficulties resolving state and traditional controls have limited the application of centralized measures for nonexport fishing activities in rural areas. Historically, rural communities dependent on fisheries have had little voice in national fisheries management and planning.

Over the last 15 years, communities and their partner agencies, predominantly international NGOs, have established over 130 locally managed marine areas. The Solomon Islands Locally Managed Marine Area (SILMMA) approach to comanagement is notable for clarifying local resource management authority by supporting state institutions to complement rather than compete with customary management regimes. NGOs typically facilitate the development of management arrangements and resource use rules that are approved through consultation with resource owners and the broader community. Compliance is promoted by strengthening local and traditional leadership, enforcement, and dispute resolution systems. NGO and government members of SILMMA are engaged in dialogue to develop legal reforms to support comanagement, including measures to increase mutual accountability between provincial and community levels. Current draft legislation would, for example, decentralize authority to provincial government agencies and formally recognize community management plans in provincial ordinances, as well as provide new formal avenues for local representation and participation in the governance of nearshore fisheries and marine resources (Govan et al. 2011).

The SILMMA network was established in 2003 by the Ministry of Fisheries and Marine Resources and NGOs. SILMMA network's objective is to promote information exchange, collaboration, and coordination across the numerous government ministries, NGOs, and communities involved in managing Solomon Islands' marine resources (Cohen et al. 2012). WorldFish has been a member since the network's establishment and has actively fostered the network by cofacilitating and cofunding network activities. The network promotes dialogue of community issues and experiences particularly via multistakeholder workshops and meetings with participation of community representatives alongside NGO and government representatives.

Despite such efforts by SILMMA network members to facilitate representation of community interests in higher levels of governance, significant obstacles remain to enhance stakeholder representation and downward accountability. Community groups are often very reliant on financial, technical, and logistical support received via their NGO partners for management activities, and for engagement in the SILMMA network. Without appropriate mechanisms to ensure autonomy, community interests may be subordinated to partner, donor, and government agendas. Community representatives in the SILMMA network are selected at the local level, generally from a local resource management committee. This selection may be arbitrary, for example, where people in positions of power become representatives by default, and as a result, representatives may not be answerable to all sectors of the community. In particular, women's representation on local resource management committees, and their formal role in decision-making processes, is often lacking (Hilly et al. 2012).

Although the SILMMA network has had some success in bridging fisheries and environment sectors, engagement with other sectors such as health, agriculture, and education has been minimal to date. Therefore, improving sector-spanning representation in decision making forums and horizontal accountability among sectoral institutions remain serious challenges. Bridging organizations like SILMMA have a role to play in dialogue to highlight, for example, how improvements in health and education services to remote communities can contribute to improvements in capacity for resource management, or how international trade policies affect domestic food security and potential for climate change adaptation. Playing such a role effectively, however, requires significant organizational capacity to bring together the sometimes competing agendas of different donors, initiatives, agencies, and local communities. It also requires improvement of communication channels to introduce local perspectives in regional and global debates that will directly influence the livelihoods of coastal communities.

\section{LESSONS AND CHALLENGES IN COMPARATIVE PERSPECTIVE}

These four case studies represent a diverse set of AAS in riverine wetland, seasonal floodplain, lakeshore, and marine environments, and in a spectrum of socio-political contexts. With reference to the case studies, we illustrate how assessing 
the governance dimensions of representation, power, and accountability can yield practical insights into opportunities for improving local livelihoods. We then extend the argument to consider how shifts in governance relate to livelihood resilience and institutional transformation.

\section{Strengthening stakeholder representation}

Building more inclusive stakeholder representation is critical given the diversity of stakeholders involved in AAS and the marginalization that many poor resource-dependent households in these systems face (Allison et al. 2012). In the Bangladesh case, coalitions of community-based organizations played a key role in helping to lobby government for community access to seasonal water bodies, and the Bangladesh Environmental Lawyers Association provided legal and administrative support. Some 250 community-based organizations in the floodplain have since established a federation, known as the Society for Water Resources Management, which continues to advocate for community tenure and management rights, and improvements in the distribution of benefits derived from these water bodies (Thompson et al. 2010, Sultana and Thompson 2011).

The example of village-led research networks in Cambodia's Stung Treng wetlands illustrates an earlier stage of supporting community capacity to articulate local interests. Downstream in Cambodia's Tonle Sap Lake, where civil society groups are more densely represented, efforts to strengthen a national grassroots network of fisherfolk and increase their capacity to collaborate and negotiate with government authorities have recently helped to secure a formal transfer of access rights to fishing communities and to resolve access disputes spanning provincial boundaries (Ratner et al. 2011). Follow-on efforts are now addressing competing uses of water and seasonal crop agriculture in the flooded forest zone, and assessing management options that balance interests in conservation and economic development.

Bridging organizations (Berkes 2002) that help communicate poor resource users voices in development decision making and help mediate interests across sectors and geographic scales are an especially important vehicle for improving equity in stakeholder representation. In the Solomon Islands example, a key challenge is increasing the influence of local resource users in national and regional policy formulation. The SILMMA network aids in this goal by providing a channel for information from communities, including community comanagement experiences, to be considered in national and international policy arenas. The network also facilitates forums for dialogue with national government agencies and international NGOs, and provides logistical and financial support to enable community members to participate. In recent interviews of SILMMA members, two-thirds of respondents felt that information provided by their organizations had already influenced national or regional policies concerning marine resource management. Mandates of SILMMA members vary, however, between conservation of biodiversity and fisheries management for livelihoods and food security, and also between longer or shorter planning horizons. Although network heterogeneity is a valuable characteristic for responding to change and uncertainty (Folke et al. 2005), in practice these differences also present challenges to network-wide information exchange, learning, and collective action (Cohen et al. 2012).

Governance challenges due to competing priorities are magnified across scales. In the case of Cambodia, for example, there is an intergovernmental institution in place to mediate transboundary river basin management, the Mekong River Commission. However, its very makeup means that local stakeholders such as riverside villagers in Stung Treng rely primarily on national government to represent their interests on matters such as construction of mainstream dams upriver in Laos. This illustrates the need for cross-scale interactions that empower local user groups rather than extend control by central government or large-scale economic actors (Adger et al. 2005).

\section{Redistributing authority}

Measures that protect or equitably redistribute rights to access, manage, and retain benefits from AAS are especially important in areas where marginalized groups have seen those rights eroded in the face of increased competition. In Bangladesh, for example, community-based fish culture has enabled improvements in income and nutrition for the landless poor and women-headed households, two groups largely excluded from participation in the prior system that enabled capture of resource rights by local elites (Haque et al. 2011). In Stung Treng, Cambodia, village members of the Salaphoum research network face increasing pressure to balance longer term conservation demands with improvements in access rights for local users to meet more immediate food production needs. Navigating these tensions is essential because livelihood security and respect for basic human rights should be understood as a precondition for participation in longer term resource management efforts (Allison et al. 2012).

In some instances, clarifying tenure arrangements for resource management can undermine cooperation between groups or act as a catalyst for conflict within communities. This has been documented in Solomon Islands, for example, in processes to establish management areas or conservation zones (McDougall 2005). The objectives of customary and state resource management institutions also may not be aligned, and these differences can present difficulties in forming hybrid institutions for coastal management (Foale et al. 2011). Traditional systems may also be inequitable and lack effective mechanisms of downward and horizontal accountability, as research in inland AAS in Sub-Saharan Africa has shown (Béné et al. 2009). 
In building capacity to resolve disputes over tenure and resource management authority, it is often useful to support linkages between parallel institutions. Comparative research on comanagement institutions in multiple lake and river systems in Malawi, for example, suggests that where local government and sectoral agencies collaborate with the traditional chiefs, fisherfolk are able to access multiple avenues of recourse in clarifying resource claims and resolving disputes (Russell and Dobson 2011). In the Pacific, many initiatives to establish marine protected areas have ignored or sidelined local tenure and dispute resolution systems, while the most successful efforts have instead acknowledged the legitimacy of these local institutions, reinforcing their authority in areas such as monitoring and enforcement (Ferse et al. 2010).

\section{Building accountability of decision makers}

Robust mechanisms of accountability are especially important at times when rights to access, use, and to deriving benefits from natural resources are being reallocated or negotiated. In the case of floodplain water bodies in Bangladesh, as community-based organizations became more active in advocating for community rights, and more effective in communicating with local government, they were able to avert elite capture in many locales. Similarly, in Cambodia a recent wave of mobilization in response to tensions between largescale and small-scale users of fisheries and agricultural land in the Tonle Sap floodplain culminated in a decision to end the regime of commercial fishing concessions. As national authorities assess options for future policy and regulatory reform, continued engagement by civil society groups, close monitoring by the media, and independent research are important mechanisms to promote public understanding and deliberation over the likely consequences of various policy options (Ratner 2011).

Even where traditional management systems may be absent, informal mechanisms of accountability are typically critical alongside more formal mechanisms. Each of the four cases summarized in this paper illustrate a range of tensions among competing users of land, fisheries, water, and wetlands, emphasizing the need for multiple routes to hold decision makers accountable, in addition to formal court proceedings. In the Lake Chilwa case, for example, support for participatory monitoring and analysis of fisheries production trends at the lake scale is influencing local stakeholders' understanding of policy and management options, bringing new voices into the policy debate, and increasing public scrutiny of management decisions. In the Cambodia case, decentralization reforms have provided an opening for local communities to take part in resource management planning alongside provincial and local authorities. However, injecting concerns over food security and livelihoods in broader development policy decision making such as plans for hydropower dams remains exceptionally difficult, despite increasing evidence of the risks (Ziv et al. 2012).

\section{Governance, livelihood resilience, and transformation}

These case studies are intended to illustrate the viability of the analytical framework in diverse settings and to sharpen description of its key dimensions. In doing so, we have also described the preliminary outcomes of action research. By identifying critical obstacles and opportunities in the governance context, researchers and development practitioners can better support efforts to strengthen livelihood resilience, and to transform the institutions that reinforce poor people's marginalization and vulnerability.

To make this connection between governance change and social-ecological system outcomes more explicit, consider several scenarios that can be drawn from the cases presented. In Bangladesh's floodplain, the case study showed how addressing elite resource capture (a shift in distribution of authority) and improving the responsiveness of local authorities to community-based planning (an enhancement in downward accountability) resulted in both increased production and more equitable distribution of benefits, spurring household investments in health and education. Should similar changes be adopted at sufficient scale, these could reasonably be evaluated as an increase in system resilience, because they strengthen the ability of poor households in particular to accommodate shocks and stresses.

In the case of Lake Chilwa, efforts that enable resource users to have a stronger voice in lake basin planning (an improvement in stakeholder representation) are showing some initial promise that could lead to more clear and balanced sharing of responsibilities for resource management (distribution of authority) and improved services. If the local demand for services to enable savings and credit is realized, it could catalyze a range of new microenterprises that increase people's capacity for adaptation in the face of climate change. Similarly, facilitation of a network in Solomon Islands for dialogue between marine resource management actors who operate across scales has provided a mechanism for local concerns and actions to be considered in national policy (enhanced stakeholder representation). Resulting legal reforms are clarifying the complementary authority of traditional and state institutions and strengthening mechanisms for downward accountability, measures which could also improve responsiveness to local needs, buttressing capacity for adaptation to ecological, social, and economic changes.

Last, to take the case of the Stung Treng wetlands in Cambodia, efforts that strengthen community voices in resource planning are helping build a broader constituency for conservation, provided that it contributes to, rather than diminishes, local 
livelihoods. If, over time, this is complemented by improvements in local powers for enforcement (distribution of authority), and if decentralization reforms make national agencies more responsive to local priorities (strengthened downward accountability), it is possible to envision a scenario in which local communities' depend much less on resource exploitation and much more on new income opportunities generated through ecotourism, with revenue reinvested in protection. Should these changes in resource use patterns, accountability, and distribution of authority become sufficiently pronounced and lasting, it could be considered a transformation in the social-ecological system at this local scale. By improving resource management and reducing conflict, such local transformations can contribute positively to resilience at larger scales (Folke et al. 2010) as well as model the sorts of transformations that may be needed at these scales (Olsson et al. 2006).

\section{CONCLUSION}

In many aquatic agricultural systems, local resource users are witnessing increased competition from multiple stakeholders at local to national and regional scales over rights to access and use natural resources, land, water, wetlands, and fisheries, essential to rural livelihoods. A key implication is the need to strengthen governance to enable equitable decision making amidst such competition. The simple analytical framework developed in this paper aims to facilitate action research to diagnose obstacles and opportunities for improving governance in developing-country aquatic agricultural systems (AAS).

The case studies we present illustrate each of the three framework dimensions, and highlight the value of long-term action research in gaining locally grounded insights. Our intention here is not to establish generalizable conclusions about the governance challenges in AAS more broadly, nor to pinpoint general priorities for governance reform. Instead, we have set out to demonstrate the practical utility of analysis oriented according to this framework in helping to identify pathways for change within a diversity of settings.

We have also shown that the framework can aid comparison of the governance context for development of AAS across countries and regions. Because the framework builds on a body of empirical research in environmental governance addressing a range of resource systems, with minor adaptations in the guiding questions and examples the framework should also be suitable for application in other agroecosystems such as drylands, pastoral systems, and mountain watersheds. If we can achieve greater consistency in the criteria used to evaluate governance characteristics across such systems, it should aid comparisons and accumulation of lessons about common obstacles and pathways to change.

Last, a sound understanding of governance contexts is critical to identifying opportunities for investment aimed at improving resilience in complex SES. When such assessments involve local stakeholders in ways that influence future programming priorities of official aid agencies, NGOs, and other development partners, this can help aid in the selection of feasible actions, as well as improve downward accountability of development initiatives to the communities they aim to serve (Blagescu et al. 2005). The dynamic and unpredictable challenges faced by fishers, farmers, and other rural resource users highlights the central importance of building the capacity of these communities to adapt in the face of future change, to participate in enhancing social-ecological resilience, and to proactively influence transformations in the institutions that maintain poverty and marginalization. Collaborative efforts to assess the governance context can help identify pathways to change as well as build shared commitment to pursuing these.

Responses to this article can be read online at: http://www.ecologyandsociety.org/issues/responses. php/6043

\section{Acknowledgments:}

For critical feedback on an early draft of this article, the authors would like to thank Neil Andrew, Boru Douthwaite, Patrick Dugan, Daniel Jamu, Ranjitha Puskur, Anne-Marie Schwarz, and especially Louisa Evans, as well as four anonymous reviewers. This paper was supported by funding from the CGIAR Research Program on Aquatic Agricultural Systems and the CGIAR Research Program on Policies, Institutions, and Markets. The analytical framework is adapted from Ratner and Allison (2012). Case studies draw on experience from partnerships supported by the Wetlands Alliance Program (funded by the Swedish International Development Cooperation Agency) in Cambodia, the Community-Based Fish Culture in Irrigation Systems and Seasonal Floodplains project (supported by the CGIAR Challenge Program on Water and Food) in Bangladesh, and the Lake Chilwa Basin Climate Change Adaptation Program (funded by the Norwegian Ministry of Foreign Affairs) in Malawi, and funding from the Coral Reef Initiatives for the Pacific and the Australian Centre for International Agricultural Research (ACIAR) for research in Solomon Islands. The authors alone are responsible for the opinions expressed.

\section{LITERATURE CITED}

Adger, W. N., K. Brown, and E. L. Tompkins. 2005. The political economy of cross-scale networks in resource comanagement. Ecology and Society 10(2): 9. [online] URL: http://www.ecologyandsociety.org/vol10/iss2/art9/ 
Agrawal, A., and J. Ribot. 1999. Accountability in decentralization: a framework with South Asian and West African cases. Journal of Developing Areas 33(4):473-502.

Allison, E. H., C. Béné, and N. L. Andrew. 2011. Poverty reduction as a means to enhance resilience in small-scale fisheries. Pages 216-237 in R. Pomeroy and N. L. Andrew, editors. Small-scale fisheries management: frameworks and approaches for the developing world. CABI, London, UK. http://dx.doi.org/10.1079/9781845936075.0216

Allison, E. H., B. D. Ratner, B. Åsgård, R. Willmann, R. Pomeroy, and J. Kurien. 2012. Rights-based fisheries governance: from fishing rights to human rights. Fish and Fisheries 13(1):14-29. http://dx.doi.org/10.1111/

j.1467-2979.2011.00405.x

Armitage, D. 2008. Governance and the commons in a multilevel world. International Journal of the Commons 2(1):7-32. [online] URL: http://www.thecommonsjournal.org/index. php/ijc/article/view/28

Bell, J. D., M. Kronen, A. Vunisea, W. J. Nash, G. Keeble, A. Demmke, S. Pontifex, and S. Andrefouet. 2009. Planning the use of fish for food security in the Pacific. Marine Policy 33:64-76. http://dx.doi.org/10.1016/j.marpol.2008.04.002

Béné, C., E. Belal, M. O. Baba, S. Ovie, A. Raji, I. Malasha, F. Njaya, M. Na Andi, A. Russell, and A. Neiland. 2009. Power, struggle, dispute and alliance over local resources: analyzing 'democratic' decentralization of natural resources through the lenses of Africa inland fisheries. World Development 37:1935-1950. http://dx.doi.org/10.1016/j. worlddev.2009.05.003

Berkes, F. 2002. Cross-scale institutional linkages: perspectives from the bottom up. Pages 293-322 in E. Ostrom, T. Dietz, N. Dolšak, P. C. Stern, S. Stonich, and E. U. Weber, editors. The drama of the commons. National Academy Press, Washington, D.C., USA.

Berkes, F. 2006. From community-based resource management to complex systems. Ecology and Society 11(1): 45. [online] URL: http://www.ecologyandsociety.org/vol11/ iss $1 / \operatorname{art} 45 /$

Blagescu, M., L. de Las Casas, and R. Lloyd. 2005. Pathways to accountability: a short guide to the GAP framework. One World Trust, London, UK.

Carothers, T., and D. de Gramont. 2011. Aiding governance in developing countries: progress amid uncertainties. Carnegie Endowment for International Peace, Washington, D. C., USA. [online] URL: http://carnegieendowment.org/files/ aiding governance.pdf

Cohen, P. J., L. S. Evans, and M. Mills. 2012. Social networks supporting governance of coastal ecosystems in Solomon
Islands. Conservation Letters 5:376-386. http://dx.doi. org/10.1111/j.1755-263X.2012.00255.X

Coral Triangle Initiative. 2009. Regional plan of action: Coral Triangle Initiative on coral reefs, fisheries and food security Coral Triangle Initiative on Coral Reefs, Fisheries, and Food Security, Jakarta, Indonesia. [online] URL: http://www. coraltriangleinitiative.org/sites/default/files/resources/CTI\% 20Regional\%20Plan\%20of\%20Action June \%2023\%202009. pdf

Dey, M. M., and M. Prein. 2006. Community-based fish culture in seasonal floodplains. NAGA 29(1\&2):21-27. [online] URL: http://www.worldfishcenter.org/resource centre/ community.pdf

Dietz, T., E. Ostrom, and P. C. Stern. 2003. The struggle to govern the commons. Science 302(5652):1907-1912. http:// dx.doi.org/10.1126/science.1091015

Ferse, S. C., M. M. Costa, K. S. Máñez, D. S. Adhuri, and M. Glaser. 2010. Allies, not aliens: increasing the role of local communities in marine protected area implementation. Environmental Conservation 37(1):23-34. http://dx.doi. org/10.1017/S0376892910000172

Flyvbjerg, B. 2006. Five misunderstandings about case-study research. Qualitative Inquiry 12(2):219-245. http://dx.doi. org/10.1177/1077800405284363

Foale, S., P. Cohen, S. Januchowski-Hartley, A. Wenger, and M. Macintyre. 2011. Tenure and taboos: origins and implications for fisheries in the Pacific. Fish and Fisheries 12:357-369. http://dx.doi.org/10.1111/j.1467-2979.2010.00395. $\underline{\mathrm{X}}$

Folke, C., S. R. Carpenter, B. Walker, M. Scheffer, T. Chapin, and J. Rockström. 2010. Resilience thinking: integrating resilience, adaptability and transformability. Ecology and Society 15(4): 20. [online] URL: http://www.ecologyandsociety. org/vol15/iss4/art20/

Folke, C., T. Hahn, P. Olsson, and J. Norberg. 2005. Adaptive governance of social-ecological systems. Annual Review of Environment and Resources 30:441-473. http://dx.doi. org/10.1146/annurev.energy.30.050504.144511

Govan, H., A.-M. Schwarz, and D. Boso. 2011. Towards integrated island management: lessons from Lau, Malaita, for the implementation of a national approach to resource management in Solomon Islands. WorldFish Center Report to SPREP, Honiara, Solomon Islands. [online] URL: http:// wWw.worldfishcenter.org/resource centre/WF_2898.pdf

Government of Malawi. 2000.Lake Chilwa State of Environment Report, Environmental Affairs Department, Ministry of Natural Resources and Environmental Affairs, Lilongwe, Malawi. 
Grindle, M. 2011. Good enough governance revisited. Development Policy Review 29(S1):S199-S221.

Halpern, G., K. Mam, and M. Dubois. 2010. The Salaphoum process in Stung Treng and Kratie: an impact assessment. WorldFish Center, Phnom Penh, Cambodia.

Haque, M., L. E. Visser, and M. M. Dey. 2011. Arrangements in seasonal floodplain management under community-based aquaculture in Bangladesh. Asian Journal of Agriculture and Development 8(1):1-18.

Hilly, Z., A.-M. Schwarz, and D. Boso. 2012. Strengthening the role of women in community-based marine resource management: lessons learned from community workshops. SPC Women in Fisheries Information Bulletin 22:29-35

Joffre, O., and N. Sheriff. 2011. Conditions for collective action: understanding factors supporting and constraining community-based fish culture in Bangladesh, Cambodia and Vietnam. WorldFish Center Studies and Reviews 2011-21. The WorldFish Center, Penang, Malaysia. [online] URL: http:// www.worldfishcenter.org/resource centre/WF 2816.pdf

Kayambazinthu, D. 1999. Synthesis of institutional arrangements for local-level management of natural resources: the case of Chimaliro. Pages 30-42 in Community-based management of Miombo Woodlands in Malawi. Forest Research Institute of Malawi, Proceedings of a National Workshop, Mangochi, Malawi.

Kooiman, J., M. Bavinck, R. Chuenpagdee, R. Mahon, and R. Pullin. 2008. Interactive governance and governability: an introduction. Journal of Transdisciplinary Environmental Studies 7(1):1-11.

Lane, M. B. 2006 Towards integrated coastal management in Solomon Islands: identifying strategic issues for governance reform. Ocean \& Coastal Management 49:421-441. http://dx. doi.org/10.1016/j.ocecoaman.2006.03.011

Leach, M., I. Scoones, and A. Stirling. 2011. Dynamic sustainabilities: technology, environment, social justice. Earthscan, London, UK.

Lebel, L., J. M. Anderies, B. Campbell, C. Folke, S. HatfieldDodds, T. P. Hughes, and J. Wilson. 2006. Governance and the capacity to manage resilience in regional social-ecological systems. Ecology and Society 11(1): 19. [online] URL: http:// www.ecologyandsociety.org/vol11/iss 1/art19/

Lemos, M. C., and A. Agrawal. 2006. Environmental governance. Annual Review of Environmental Resources 31: 297-335. http://dx.doi.org/10.1146/annurev.energy.31.042605.135621

Mam, K. 2009. Fisheries sector policy, legal and institutional framework in Cambodia: is there a place for strengthening decentralization? Pages 281-296 in CBNRM Learning
Institute. Emerging trends, challenges and innovations: community based natural resource management (CBNRM) in Cambodia. Second edition. CBNRM Learning Institute, Phnom Penh, Cambodia. [online] URL: http://www.boellcambodia.org/downloads/CBNRM full document.pdf

McDougall, D. 2005. The unintended consequences of clarification: development, disputing, and the dynamics of community in Ranongga, Solomon Islands. Ethnohistory 52 (1):81-109. http://dx.doi.org/10.1215/00141801-52-1-81

National Statistics Office (NSO). 2008. Malawi population and housing census. National Statistical Office, Zomba, Malawi.

Njaya, F. 2007. Governance challenges for the implementation of fisheries co-management: experiences from Malawi. International Journal of the Commons 1(1):137-153.

Njaya, F. J. 2009. Governance of Lake Chilwa common pool resources: evolution and conflicts. Development Southern Africa 26(4):663-676. http://dx.doi.org/10.1080/03768350903181431

Njaya, F., K. A. Snyder, D. Jamu, J. Wilson, C. HowardWilliams, E. H. Allison, and N. L. Andrew. 2011. The natural history and fisheries ecology of Lake Chilwa, southern Malawi. Journal of Great Lakes Research 37(1):15-25. http:// dx.doi.org/10.1016/j.jglr.2010.09.008

Olsson, P., L. H. Gunderson, S. R. Carpenter, P. Ryan, L. Lebel, C. Folke, and C. S. Holling. 2006. Shooting the rapids: navigating transitions to adaptive governance of socialecological systems. Ecology and Society 11(1): 18. [online] URL: http://www.ecologyandsociety.org/vol11/iss1/art18/

Ostrom, E. 2009. A general framework for analyzing sustainability of social-ecological systems. Science 325:419-422. http://dx.doi.org/10.1126/science.1172133

Patton, M. Q. 1990. Qualitative evaluation and research methods. Sage, Newbury Park, California, USA.

Ratner, B. D. 2011. Common-pool resources, livelihoods, and resilience: critical challenges for governance in Cambodia. IFPRI Discussion Paper Series no. 1149. International Food Policy Research Institute, Washington, D.C., USA. [online] URL: http://www.ifpri.org/publication/common-pool-resources$\underline{\text { livelihoods-and-resilience }}$

Ratner, B. D., and E. H. Allison. 2012. Wealth, rights, and resilience: an agenda for governance reform in small-scale fisheries. Development Policy Review 30(4):371-398. http:// dx.doi.org/10.1111/j.1467-7679.2012.00581.x

Ratner, B. D., G. Halpern, and K. Mam. 2011. Catalyzing collective action to address natural resource conflict: lessons from Cambodia's Tonle Sap Lake. Collective Action and 
Property Rights Working Paper No. 103. International Food Policy Research Institute, Washington, D.C., USA. [online] URL: http://www.capri.cgiar.org/pdf/capriwp103.pdf

Ratner, B. D., R. Meinzen-Dick, C. May, and E. Haglund. 2013. Resource conflict, collective action, and resilience: an analytical framework. International Journal of the Commons 7(1). [online] URL: http://www.thecommonsjournal.org/ index.php/ijc/article/view/276

Ribot, J. C. 2002. Democratic decentralization of natural resources: institutionalizing popular participation. World Resources Institute, Washington, D.C., USA.

Royal Government of Cambodia (RGC). 2006. Law on fisheries. NS/RKM/506/011. RGC, Phnom Penh, Cambodia. [online] URL: http://www.opendevelopmentcambodia.net/ pdf-viewer/?pdf=/law/en/LAW-0506-011-06-Fishery-Law-E. pdf

Royal Government of Cambodia (RGC). 2008a. Protected area law. RGC, Phnom Penh, Cambodia. [online] URL: $\underline{\text { htp:// }}$ www.opendevelopmentcambodia.net/pdf-viewer/?pdf=/law/en/ LAW-0208-007-08-Natural-Protected-Areas-E.pdf

Royal Government of Cambodia (RGC). 2008b. Law on administrative management of the capital, provinces, municipalities, districts and khans. NS/RKM/0508/017. RGC, Phnom Penh, Cambodia. [online] URL: http://www.cdc-crdb. gov.kh/cdc/twg network/country_systems_cambodia/ strengthening_national_systems/documents_for_reform/sndd/ organic law 2008 en.pdf

Russell, A. J. M., and T. Dobson. 2011. Chiefs as critical partners for decentralized governance of fisheries: an analysis of co-management case studies in Malawi. Society \& Natural Resources 24(7):734-750. http://dx.doi.org/10.1080/089419$\underline{20.2010 .501432}$

Salaphoum. 2009. Learning from experiences: reflection on the Salaphoum villager led research process. A documentation by Salaphoum Researchers, Research Assistants, CEPA and produced by villagers through a collaborative writing process and facilitated by The WorldFish Center, Phnom Penh, Cambodia.

Sultana, P., and P. Thompson. 2011. Learning through networking: enabling an adaptive learning network of local communities for integrated floodplain management in Bangladesh. Pages 138-176 in H. R. Ojha, A. Hall, and R. Sulaiman, editors. Adaptive collaborative approaches in natural resource management. Routledge, New York, New York, USA.

Thompson, P., P. Sultana, and R. Arthur. 2010. Integrating biological conservation into management: community adaptive learning in the wetlands of Bangladesh. Biodiversity 11(1-2):31-38. http://dx.doi.org/10.1080/14888386.2010.9712644
Thorburn, C. C. 2000. Changing customary marine resource management practice and institutions: the case of Sasi Lola in the Kei Islands, Indonesia. World Development 28:1461-1479. http://dx.doi.org/10.1016/S0305-750X(00)00039-5

Toufique, K. A., and R. Gregory. 2008. Common waters and private lands: distributional impacts of floodplain aquaculture in Bangladesh. Food Policy 33:587-594. http://dx.doi. org/10.1016/j.foodpol.2008.04.001

Walker, B. H., C. S. Holling, S. R. Carpenter, and A. Kinzig. 2004. Resilience, adaptability and transformability in socialecological systems. Ecology and Society 9(2): 5. [online] URL: http://www.ecologyandsociety.org/vol9/iss2/art5

Walker, B., J. Sayer, N. L. Andrew, and B. Campbell. 2010. Should enhanced resilience be an objective of natural resource management research for developing countries? Crop Science 50:10-19.

Whyte, W. F. 1984. Learning from the field: a guide from experience. Sage, Newbury Park, California, USA.

Wilson, J. A. 2006. Matching social and ecological systems in complex ocean fisheries. Ecology and Society 11(1): 9. [online] URL: http://www.ecologyandsociety.org/vol11/iss1/ $\underline{\operatorname{art} 9 /}$

WorldFish Center. 2011. CGIAR Research Program: Aquatic Agricultural Systems. Program Brief. WorldFish Center, Penang, Malaysia. [online] URL: http://www.worldfishcenter. org/resource centre/WF 2934.pdf

Ziv, G., E. Baran, S. Nam, I. Rodríguez-Iturbe, and S. A. Levin. 2012. Trading-off fish biodiversity, food security, and hydropower in the Mekong River Basin. Proceedings of the National Academy of Sciences 109:5609-5614. http://dx.doi. org/10.1073/pnas.1201423109 